\title{
Synthesis and Biological evalution of some substituted 2-dibenzyl amino 1,3,4-oxadiazoles, thiadiazoles and 1,2,4-triazoles
}

Khalid M.Daoud*

\section{Shaima S.Ismmaeel**}

*Pharmaceutical Chemistry Department,College of Pharmacy, University of Mosul

**Chemistry Department, College of Education, University of Mosul

الخلاصة

تم في هذا البحث تحضير بعض معوضات 2 ثنائي بنزيل 4 4،1 - اوكسادايازول , ثايادايازول و 1،2، 4-ترايازول المشتقة من ثنائي بنزيل امين. تم مفاعلة ثنائي بنزيل الامين مع بائ حامض كلورو الخليك لتعطي N , N - ثنائي بنزيل كلايسين (1) والذي حول الى مثيل / لتئيل ايثيل استر ( 2, 3) • تم معاملة الاسترات مع الهيدرازين المائي في الايثانول ليعطي الهيدرازيد (4) والذي تفاعل مع ثايوسيانات الامونيوم ليعطي ثايوسيماكاربازيد (5). اعطت معاملة الثايوسيماكاربازيد مع حامض الكبريتيك المركز والهيدرازين المائي و 4 \% هيدروكسيد

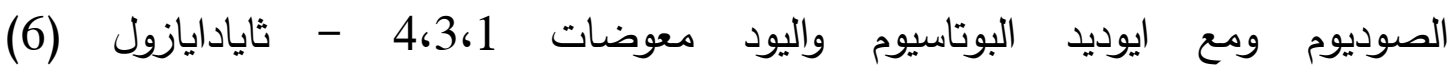
و4،2، - ترايازول (7) , 4،2، - ترايازول 3- ثايول (8) و5- امينو- 4،3، اوكسادايازول (9) على التوالي.

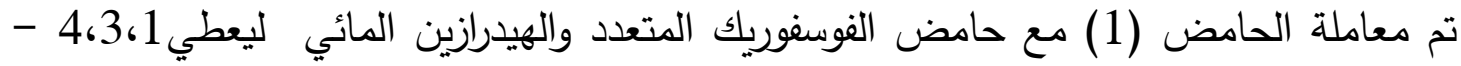
اوكسادايازول 2،5 - ثنائي التعويض (10), ومن ثم سلفنته ليعطي 4،3، - ثاياداديازول ثنائي التعويض (11) بينما اعطت مفاعلة الهيدرازيد مع كلوريدات الحوامض ثنائي الكيتون

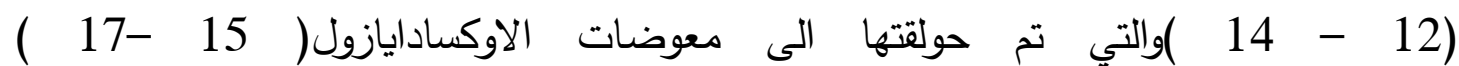
والثايادايزول( 18 - 20 ) بواسطة تفاعلها مع خماسي اوكسيد الفسفور وخماسي كبريتيد

\section{ABSTRACT}

In this paper the synthesis of some substituted 2-dibenzyl 1,3,4-oxadiazole, thiadiazole and 1,2,4-triazoles derived from dibenzyl amine is reported scheme- 1 .

Presented at the second conference on Chemistry, University of

Mosul, college of Education, 17-18 Novamber-2013. 
Dibenzyl amine was treated with chloroacetic acid to give N,N -dibenzyl glycine (1) which was converted to its methyl/ ethyl esters $(2,3)$.The esters were treated with hydrazine hydrate in ethanol to give hydrazide (4)which was reacted with ammounium thiocyanate to give thiosemicarbazide(5).Treatment of thiosemicarbazid(5)with concentrated sulfuric acid, hydrazine hydrate, $4 \%$ sodium hydroxide and with potassium iodide / iodine to gave substituted 1,3,4-thiadiazole (6) 1,2,4triazole (7) 1,2,4-triazole -3-thiol (8) and 5-amino1,3,4-oxadiazole (9) respectively.

The acid (1) was treated with polyphosphoric acid and hydrazine hydrate to give 2,5- disubstituted oxadiazole (10), sulfonation of (10) gave disubstituted 1,3,4- thiadiazole (11). Hydrazides (4) was treated with acid chlorides to give thediketones (12-14) which cyclized to substituted oxadiazoles (15-17) and thiadiazoles (18-20) by their reaction with phosphorus pentoxideand phosphorus pentasulfide respectively. Some of the synthesized compounds were tested against various types of bacteria. The structures of the synthesized compounds were confirmed by physical and spectral methods.

\section{INTRODUCTION}

Five membered rings heterocyclic compounds as 1,3,4 - oxadiazole, thiadiazole and 1,2,4 - triazole and their derivatives are will known as biologically active and used in various ways. 1,3,4 - oxadiazole derivatives were synthesized from the reaction of acid hydrazide, $4-$ mortholeno -3 - nitro phenyl hydrazide with carbon disulfide and potassium hydroxide in ethanol by refluxing the reaction mixture for 16 $\mathrm{hr}^{(1)}$
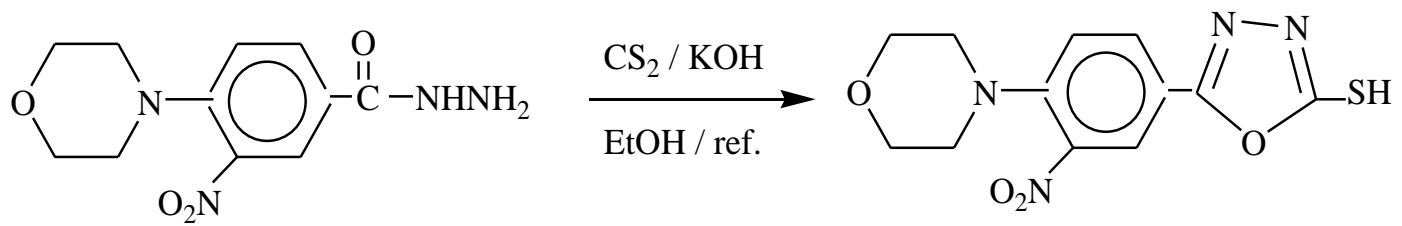

Acid hydrazide was treated with cyanogen bromide ${ }^{(2)}$ to give 1,3,4oxadiazole. Phosphorus oxychloride was used for the synthesis of disubstituted 1,3,4 - oxadiazole as compound (1) from acid hydrazid and carboxylic acid (3,4) substituted 1,3,4 - oxadiazole was synthesized using microwave technique ${ }^{(5)}$.<smiles>Cc1ccc(-c2nnc(-c3ccc(C)cc3)o2)cc1</smiles>

(1)<smiles>CC1=C(c2nnc(N)o2)C([Al])NC(=O)N1</smiles>

(2) 
1,3,4 - oxadiazoles $(3,4)$ were showed biological activities on revous system and as anti - inflammatery agent. ${ }^{(6,7)}$<smiles>[R]c1nnc(C([R])([R])Oc2ccc([R])c([R])c2)o1</smiles>

(3)<smiles>[R]c1cccc(CC(Cc2cccc([R])c2)c2nnc([R])o2)c1</smiles>

(4)

1,3,4 - Thiadiazole were synthesized from phthalic anhydride with thiocemicarbazide in presence of glacial acetic acid then cyclization of the product to thiadiazole with concentrated sulfuric acid ${ }^{(8)}$

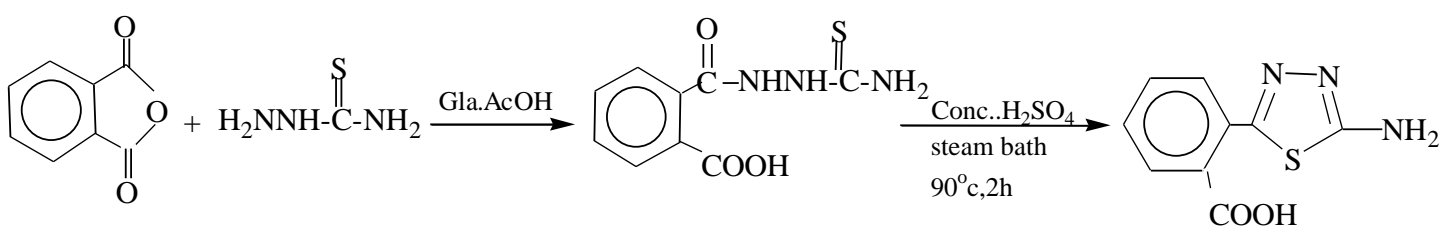

or from cyclization of substituted thiosemicarbazide with methyl sulfonic $\operatorname{acid}^{(9)}$ as (5). 1,3,4-Thiadiazoles shows various biological activities ${ }^{(10,11)}$ as antibacterial. ${ }^{(12)} 1,2,4$-Triazole 3-thiol derivatives as(6) were synthesized from substituted thiosemicarbazide by their reaction with sodium hydroxide ${ }^{(13)}$.<smiles>CCNc1nnc(Cc2ccccc2)s1</smiles>

(5)

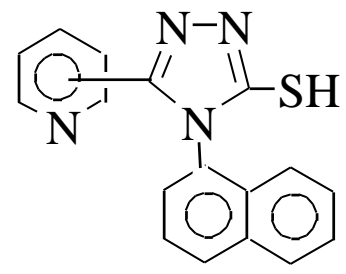

(6)

5-substituted -4- amino 1,2,4- triazole-3-thiol was obtained from potassium thiocarbazite by its treatment with hydrazine hydrate ${ }^{(14,15)}$ whereas 4-amino -3,5-diphenyl 1,2,4-triazole was synthesized by heating benzoic acid hydrazide at $200^{\circ} \mathrm{C}^{(16)}$. Some substituted 1, 2, 4 - triazoles shows various biological activities as anticancer ${ }^{(17)}$.

\section{EXPERIMENTAL}

All chemicals were purchased from Flucka and BDH Chemical Ltd.The melting points were measued on an Electrothermal 9300 Engineering LTD and are uncorrecterd .IR spectra were recorded on Infrared Spectrophotometer Model Tensor 27 ,Bruker Co.,Germany, 
using $\mathrm{KBr}$ discs . UV spectra were recorded on Shimadzu Double-Beam Spectrophotometer UV-210 A using ethanol as a solvent.

$\mathbf{N}, \mathbf{N}$ - dibenzyl glycine $(\mathbf{1})^{(18)}$

Chloroacetic acid $(1.5 \mathrm{~g}, 0.015$ mole) was dissolved in water to this solution dibenzyl amine $(3 \mathrm{~g}, 0.015 \mathrm{~mole})$ and sodium hydroxide $(0.6 \mathrm{~g} / 2 \mathrm{ml}$ $\mathrm{H}_{2} \mathrm{O}$ ) were added. The mixture was refluxed for $1.5 \mathrm{hr}$. (the oily drops material disappears and give clear solution). The mixture then cooled to room temperature and neutralized with $5 \%$ hydrochloric acid, the precipitate was filtered to give white powder, m.p. $181-183^{\circ} \mathrm{C}$,yield $79 \%$

Methyl/Ethyl N,N - dibenzyl glycinate $(\mathbf{2}, 3)^{(19)}$

A mixture of $\mathrm{N}, \mathrm{N}-$ dibenzyl amine (0.02 mole, 4g), methyl bromoacetate $(0.02$ mole, $3 \mathrm{~g})$ and sodium bicarbonate $(3 \mathrm{~g})$ in absolute ethanol $(30 \mathrm{ml})$ was refluxed for $5 \mathrm{hr}$. the solvent was evaporated and the residual poured on crushed ice with stirring, the precipitated was filtered off, dried as white yellowish powder(2), m.p. $\left(40-42^{\circ} \mathrm{C}\right)$, yield $82 \%$ and yellow powder(3) m.p. $\left(50-52^{\circ} \mathrm{C}\right)$, yield $86 \%$

\section{N,N-dibenzyl glycine hydrazide $(4)^{(20)}$}

Ester ( 2 or 3$)$ ( 0.015 mole) and hydrazine hydrate $(4 \mathrm{ml}, 0.07$ mole $)$ in absolute ethanol $(40 \mathrm{ml})$ were refluxed for $5 \mathrm{hr}$. the solvent was evaporated under reduced pressure to give white - yellowish crystals (m.p. $112-114^{\circ} \mathrm{C}$ ) yield, ester (2) $83 \%$, ester (3) $94 \%$.

1 - (dibenzyl amino acetyl) thiosemicarbazide $(5)^{(2)}$

A mixture of hydrazide (4)( $3 \mathrm{~g}, 0.0116$ mole $)$, ammonium thiocyanate $(2.7 \mathrm{~g}, 0.034$ mole $)$ and concentrated hydrochloric and in absolute ethanol $(50 \mathrm{ml})$ was refluxed for $22 \mathrm{hr}$. the solvent was evaporated under reduced pressure, precipitate was filtered off and recrystallized from ethanol, m.p. $236^{\circ} \mathrm{C}$, yield: $74 \%$.

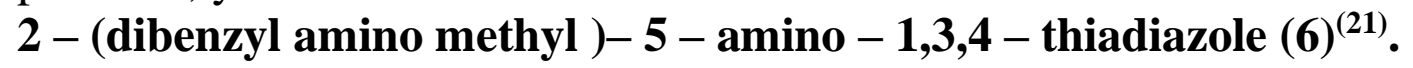

A mixture of substituted thiosemicarbazide (5) ( $2 \mathrm{~g}, 0.006$ mole) and concentrated sulfuric acid $(12 \mathrm{ml})$ was stirred at room temperature for $1 \mathrm{hr}$. then heated on water path at $90^{\circ} \mathrm{C}$ for $2 \mathrm{hr}$. with stirring. The mixture was poured on crushed ice and neutralized with concentrated ammonium hydroxide with cooling, the precipitate was filtered off, washed with cold water dried and recrystallized from ethanol, green powder m.p. $151-153^{\circ} \mathrm{C}$, yield $17 \%$.

3,4 - diamino - 5 - (dibenzyl amino methyl) $-1,2,4-$ triazole $_{(7)^{(22)}}$.

A mixture of thiosemicarbazide (5) $(1.6 \mathrm{~g}, 0.005$ mole) and hydrazine hydrate $(5 \mathrm{ml}, 0.1$ mole) was refluxed for $2 \mathrm{~h}$. the mixture was cooled, and the precipitated filtered off, washed with water, dried, gave white powder, m.p. $208-210^{\circ} \mathrm{C}$, yield $22 \%$.

5 - (dibenzyl amino methyl) - 1,2,4 - triazole -3 -thiol $(8)^{21}$

Thiosemicarbazide (5), (2g, 0.006 mole)in sodium hydroxide solution $(4 \%, 24 \mathrm{ml})$ was refluxed for $3 \mathrm{hr}$. the mixture was acidified with dilute 
hydrochloric acid with cooling $\mathrm{PH}=6$, the precipitated was filtered off, and recrystallized from ethanol - water to give white powder m.p. > $300^{\circ} \mathrm{C}$ yield $88 \%$

2 - (dibenzyl amino methyl) -5 - amino $-1,3,4$-oxadiazole $(9)^{23}$.

To thiosemicarbazide $(5)(2.5 \mathrm{~g}, 0.0074$ mole $)$ in ethanol $(15 \mathrm{ml}), 4 \mathrm{~N}$ sodium hydroxide solution then 5\% I2/KI was added slowly with stirring (the color of iodine is appears). The product was extracted with ether $\left(2^{\times} 20 \mathrm{ml}\right)$, the ether layer dried with magnesium sulfate, evaporated to give yellow oil, yield, $65 \%$.

2,5 - Bis (dibenzyl amino methyl) - 1,3,4 - oxadiazole $(10)^{24}$

Carboxylic acid (1)(7,4g, 0.026 mole) and hydrazine hydrate $(0.65 \mathrm{ml}$, 0.013 mole) were added to polyphosphoric acid $(27 \mathrm{~g})$ respectively. The mixture was heated at $150^{\circ} \mathrm{C}$ for $15 \mathrm{hr}$ with stirring, cooled, then powered on crushed ice, neutralized with 5\% sodium bicarbonate solution, pale brown precipitate formed, filtered, dried and recrystallized from ethanol. m.p. : $121-123^{\circ} \mathrm{C}$, yield, $57 \%$.

2,5 - Bis (dibenzyl amino methyl) - 1,3,4 - thiadiazole $(11)^{25}$.

A mixture of oxadiazole (10)(1,2 g,0.0025 mole) and thiourea $(0.76 \mathrm{~g}$, 0.01 mole) in xylene $(30 \mathrm{ml})$ was refluxed for $30 \mathrm{hr}$. the solvent was evaporated under reduced pressure to give solid precipitate, filtered off and recrystallized from ether - pt. ether $\left(40-60^{\circ} \mathrm{C}\right)$, m.p. $160-162$, yield $88 \%$

\section{1,2 - Diacyl hydrazine $(12-14)^{26}$.}

Hydrazide (4) ((3g, 0.011 mole) was dissolved in dry tetrahydrofuran $(50 \mathrm{ml})$, acid chloride $(0.11$ mole) was added slowly with stirring and cooling, the mixture was refluxed for $12 \mathrm{~h}$, cool to room temperature and poured on to crushed ice and the mixture neutralized with $15 \%$ sodium bicarbonate, the product filtered off, dried and recrystallized from ethanol.

2 - (dibenzyl amino methyl) -5 - substituted $-1,3,4$ - oxadiazole $(15-17)^{27}$.

A mixture of diacyl hydrazine(12-14) (0.0064 mole) and phosphorus pentaxide $(0.17 \mathrm{~g}, 0.0012$ mole $)$ in xylene $(25 \mathrm{ml})$ was refluxed for $12 \mathrm{~h}$, the solvent was evaporated under reduced pressure and the product recrystallized from ethanol.

\section{2 - (dibenzyl amino methyl) - 5 - substituted - 1,3,4 - thiadiazole $(\mathbf{1 8 - 2 0})^{28}$.}

A mixture of diacyl hydrazine $(12-14)(0.0064$ mole $)$ and phosphoric pentasulfide $(0.26 \mathrm{~g}, 0.0012 \mathrm{~mole})$ in xylene $(25 \mathrm{ml})$ was refluxed for $12 \mathrm{~h}$. the solvent was evaporated under reduced pressure and the product was recrystallized from ethanol - water . 
Table(1) :Physical data of compounds(12-20)

\begin{tabular}{|c|c|c|c|c|c|}
\hline Comp.No. & $\mathrm{R}$ & m.p & $\begin{array}{c}\text { Molecular } \\
\text { formula }\end{array}$ & $\begin{array}{c}\text { Yield } \\
\%\end{array}$ & Color \\
\hline 12 & $\mathrm{CH}_{3}$ & $72-74$ & $\mathrm{C}_{18} \mathrm{H}_{21} \mathrm{~N}_{3} \mathrm{O}_{2}$ & 56 & Palebrown \\
\hline 13 & $\mathrm{Ph}$ & $205-207$ & $\mathrm{C}_{23} \mathrm{H}_{23} \mathrm{~N}_{3} \mathrm{O}_{2}$ & 66 & White \\
\hline 14 & $4-\mathrm{NO}_{2}-\mathrm{C}_{6} \mathrm{H}_{4}$ & $124-126$ & $\mathrm{C}_{23} \mathrm{H}_{22} \mathrm{~N}_{4} \mathrm{O}_{4}$ & 74 & Pale yellow \\
\hline 15 & $\mathrm{CH}_{3}$ & Oily & $\mathrm{C}_{18} \mathrm{H}_{19} \mathrm{~N}_{3} \mathrm{O}$ & 29 & yellow \\
\hline 16 & $\mathrm{Ph}$ & $212-214$ & $\mathrm{C}_{23} \mathrm{H}_{21} \mathrm{~N}_{3} \mathrm{O}$ & 36 & Yellowish white \\
\hline 17 & $4-\mathrm{NO}_{2} \mathrm{C}_{6} \mathrm{H}_{4}$ & $132-134$ & $\mathrm{C}_{23} \mathrm{H}_{20} \mathrm{~N}_{4} \mathrm{O}_{3}$ & 62 & Yellow \\
\hline 18 & $\mathrm{CH}_{3}$ & Oily & $\mathrm{C}_{18} \mathrm{H}_{19} \mathrm{~N}_{3} \mathrm{~S}$ & 21 & Yellow \\
\hline 19 & $\mathrm{Ph}_{2}$ & $117-119$ & $\mathrm{C}_{23} \mathrm{H}_{21} \mathrm{~N}_{3} \mathrm{~S}$ & 20 & Yellowish brown \\
\hline 20 & $4-\mathrm{NO}_{2} \mathrm{C}_{6} \mathrm{H}_{4}$ & $72-74$ & $\mathrm{C}_{23} \mathrm{H}_{20} \mathrm{~N}_{4} \mathrm{O}_{2} \mathrm{~S}$ & 90 & Pale brown \\
\hline
\end{tabular}

\section{RESULTS AND DISCUSSION}

Substituted 2 -dibenzyl amino methyl 1,3,4- oxadiazoles, thiadiazoles and 1,2,4-triazoles were synthesized from dibenzylamine Scheme-1. Dibenzyl amine was treated with chloroacetic acid to give N,N - dibenzyl glycine (1) which show absorption at $1710 \mathrm{~cm}^{-1}$ for $(\mathrm{C}=\mathrm{O}$, acid $)$, the acid (1) was converted to methyl/ethyl esters $(3,4)$, the IR spectra show absorption for carbonyl group of the esters at $1728,1747 \mathrm{~cm}^{-1}$. the esters $(3,4)$ were treated with hydrazide hydrate in ethanol to give hydrazine (4) the $(\mathrm{C}=\mathrm{O})$ group in (4) shows absorption at $1665 \mathrm{~cm}^{-1}$. the hydrazide (4) was treated with ammonium thiocyanate to give thiosemicarbazide (5), the IR of compound (5) shows absorption at $1665 \mathrm{~cm}^{-1}$ for $(\mathrm{C}=\mathrm{O})$ and $3379(\mathrm{~N}-\mathrm{H})$. the thiosemicarbazide (5) was treated with concentrated sulfuric acid to give 1,3,4 - thiadiazole derivatives (6), while its reaction with hydrazine hydrate, $4 \%$ sodium hydroxide and with potassium iodide/iodine gave 3,4 - diamino - 5 - N,N - dibenzyl amino methyl 1,2,4 - triazole (7), 1,2,4 - triazole - 3 - thiol (8) and 5 - amino 1,3,4 oxadiazole (9) respectively. The IR spectra of compounds $(6-9)$ shows absorption at $1620-1652 \mathrm{~cm}^{-1}(\mathrm{C}=\mathrm{N}) 3311-3424 \mathrm{~cm}^{-1}(\mathrm{~N}-\mathrm{H})$, compound (8) show absorption at $1201(\mathrm{C}=\mathrm{S})$. compound (10) was synthesized from (1) with polyphosphoric acid and hydrazine hydrate, sulfonation of (10) gave disubstituted 1,3,4 - thiadiazole (11). Hydrazide (4) was treated with some acid chlorides to give diketones $(12-14)$, the IR spectra shows absorption at $1654-1671 \mathrm{~cm}^{-1}$ for $(\mathrm{C}=\mathrm{O})$, the diketones $(12-14)$ then cyclized to substituted oxadiazoles $(15-17)$ and thiadiazoles $(18-20)$ by their reaction with phosphorus peutoxide and with phosphorus peutasulfide respectively. The IR spectra show absorption at $1635-1670 \mathrm{~cm}^{-1}$ Scheme -2 . The UV and IR spectra listed at table (2).

Some of the synthesized compounds were tested against various types of bacteria and showed certain activities. Table (3) 
Table(2): IR and UV data of the synthesized compounds .

\begin{tabular}{|c|c|c|c|c|c|}
\hline \multirow{2}{*}{$\begin{array}{l}\text { Comp. } \\
\text { No. }\end{array}$} & \multirow{2}{*}{$\begin{array}{c}\mathrm{UV} \\
(\mathrm{EtOH}) \\
\lambda_{\max }(\mathrm{nm}) \\
\end{array}$} & \multicolumn{4}{|c|}{ IR $v \mathrm{~cm}^{-1},(\mathrm{KBr})$} \\
\hline & & $\mathrm{C}=\mathrm{O}$ & N-H & $\mathrm{C}=\mathrm{N}$ & Others \\
\hline 1 & & 1710 & - & & $\begin{array}{c}\mathrm{OH}: 3450 \\
\text { Ar-C-H:3086 }\end{array}$ \\
\hline 2 & 235,271 & 1728 & - & & Ar-C-H:3030 \\
\hline 3 & 266,317 & 1747 & - & & Ar-C-H:3027 \\
\hline 4 & 242,308 & 1665 & 3348 & & Ar-C-H:3058 \\
\hline 5 & 238,280 & 1665 & 3379 & - & \\
\hline 6 & 295,336 & - & 3313 & 1620 & CS:1029 \\
\hline 7 & 301.266 & - & 3423 & 1624 & Ar-C-H:3025 \\
\hline 8 & 284,360 & - & 3424 & 1640 & $\mathrm{C}=\mathrm{S}: 1201$ \\
\hline 9 & 293 & - & 3311 & 1652,1616 & $\begin{array}{c}\text { C-OC:1204 } \\
\text { Ar-C-H:3062 }\end{array}$ \\
\hline 10 & 239,265 & - & - & 1624 & $\begin{array}{c}\text { ArC-H 3028 } \\
\text { C-O-C1294,1110 }\end{array}$ \\
\hline 11 & 228,288 & - & - & 1625 & $\begin{array}{l}\text { C-S-C: } 1084 \\
\text { ArC-H:3100 }\end{array}$ \\
\hline 12 & 236,265 & 1654 & 3323 & - & ArC-H:3026 \\
\hline 13 & 238,302 & 1668 & 3424 & - & $\mathrm{ArC}-\mathrm{H}: 3080$ \\
\hline 14 & 283,323 & 1671 & 3375 & - & $\begin{array}{c}\mathrm{NO}_{2}: 1346 \text { Sy. } \\
1529 \text { asy. } \\
\text { ArC-H:3062 }\end{array}$ \\
\hline 15 & 237,295 & - & - & 1635 & $\begin{array}{c}\mathrm{C}-\mathrm{O}- \\
\mathrm{C}: 1115,1182 \\
\text { ArC-H:3094 }\end{array}$ \\
\hline 16 & 243,280 & - & - & 1667 & $\begin{array}{c}\text { C-O- } \\
\text { C: } 1108,1287 \\
\text { ArC-H:3052 }\end{array}$ \\
\hline 17 & 235,248 & - & - & 1604 & $\begin{array}{c}\text { C-O-C: } 1108,125 \\
\text { ArC-H: } 3029 \\
\mathrm{NO}_{2}: 1346.1493\end{array}$ \\
\hline 18 & 238,277 & - & - & 1637 & $\begin{array}{c}\text { ArC-H:3061 } \\
\text { C-S-C:1120 }\end{array}$ \\
\hline 19 & 248,304 & - & - & 1640 & $\begin{array}{c}\text { ArC-H:3027 } \\
\text { C-S-C:1028 }\end{array}$ \\
\hline 20 & 241,311 & - & - & 1670 & $\begin{array}{c}\text { ArC-H:3060 } \\
\text { C-S-C : } 1159 \\
\text { NO2:1345Sy. } \\
\text { 1521asy. }\end{array}$ \\
\hline
\end{tabular}


Synthesis and Biological evalution of some substituted 2-dibenzyl .....

Table(3): The antibacterial activity of the tested compounds

\begin{tabular}{|c|c|c|c|c|c|c|c|c|c|c|c|c|c|c|c|c|c|c|c|c|c|}
\hline \multirow{3}{*}{\multicolumn{2}{|c|}{ Comp.No. }} & \multicolumn{4}{|c|}{$\begin{array}{c}\text { Staphylococcus } \\
\text { aureus }\end{array}$} & \multicolumn{4}{|c|}{ Bacillus subtilis } & \multicolumn{4}{|c|}{$\begin{array}{l}\text { Moraxella } \\
\text { catarrhalis }\end{array}$} & \multicolumn{4}{|c|}{$\begin{array}{l}\text { Haemophilus } \\
\text { influenza }\end{array}$} & \multicolumn{4}{|c|}{$\begin{array}{l}\text { Klebsiella } \\
\text { pneumonia }\end{array}$} \\
\hline & & \multicolumn{20}{|c|}{ Conc. ( $\mathrm{mg} / \mathrm{ml}$ ) } \\
\hline & & 10 & 1 & 0.1 & 0.01 & 10 & 1 & 0.1 & 0.01 & 10 & 1 & 0.1 & 0.01 & 10 & 1 & 0.1 & 0.01 & 10 & 1 & 0.1 & 0.01 \\
\hline \multicolumn{2}{|l|}{1} & 7 & 4 & 2 & -- & 6 & 4 & -- & -- & 8 & 5 & 3 & -- & 9 & 5 & 2 & -- & 8 & 5 & 2 & -- \\
\hline \multicolumn{2}{|l|}{3} & 5 & 3 & -- & -- & 7 & 4 & 2 & -- & 5 & 3 & -- & -- & 6 & 3 & -- & -- & 8 & 4 & 2 & -- \\
\hline \multicolumn{2}{|l|}{4} & 8 & 4 & 2 & -- & 8 & 5 & 3 & -- & 10 & 6 & 3 & -- & 10 & 7 & 4 & -- & 6 & 3 & -- & -- \\
\hline \multicolumn{2}{|l|}{5} & 9 & 5 & 3 & -- & 8 & 5 & 2 & -- & 8 & 5 & 2 & -- & 8 & 4 & 2 & -- & 10 & 7 & 5 & -- \\
\hline \multicolumn{2}{|l|}{6} & 6 & 3 & -- & -- & 7 & 5 & 3 & -- & 6 & 4 & -- & -- & 8 & 5 & 2 & -- & 7 & 4 & 2 & -- \\
\hline $\begin{array}{l}\text { Ceftriaxone } \\
\text { 30mg/disk }\end{array}$ & \multirow{2}{*}{ 它 } & \multicolumn{4}{|c|}{19} & \multicolumn{4}{|c|}{16} & \multicolumn{4}{|c|}{20} & \multicolumn{4}{|c|}{22} & \multicolumn{4}{|c|}{21} \\
\hline $\begin{array}{l}\text { Norfloxacin } \\
10 \mathrm{mg} / \text { disk }\end{array}$ & & \multicolumn{4}{|c|}{18} & & & 16 & & \multicolumn{4}{|c|}{24} & & & 19 & & \multicolumn{4}{|c|}{27} \\
\hline
\end{tabular}




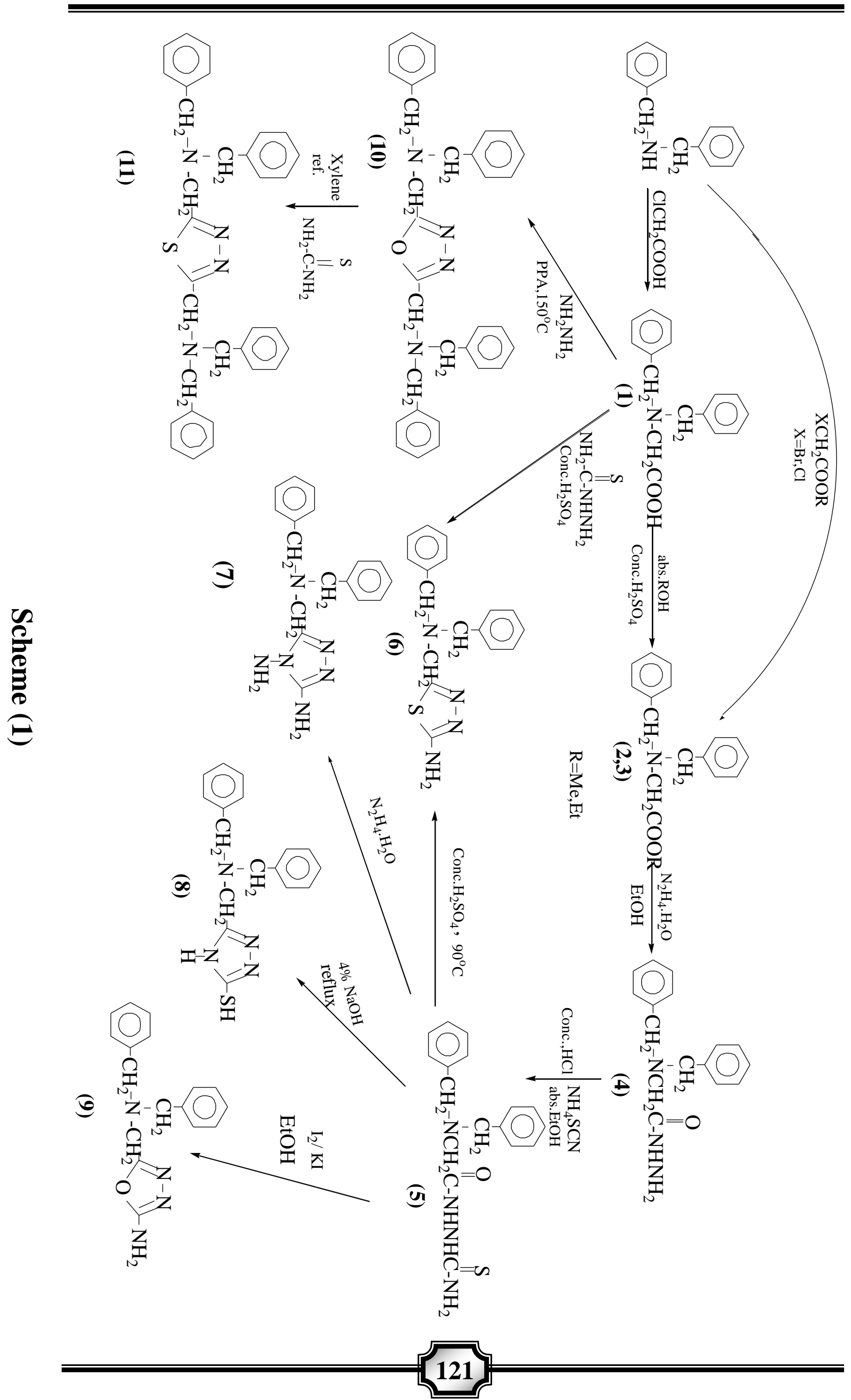




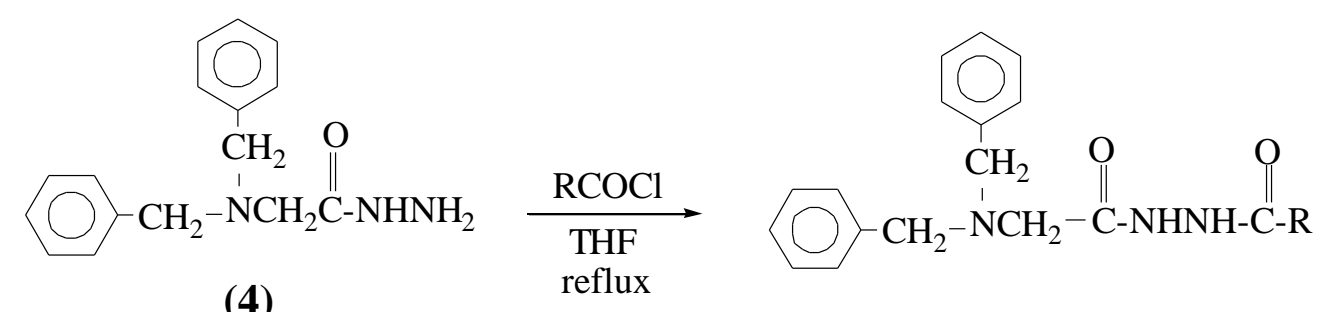

(4)

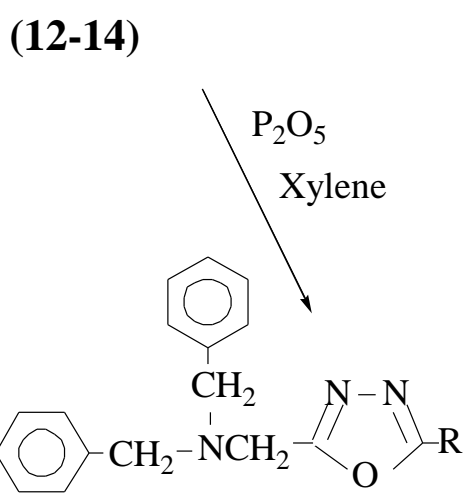

(15-17

$\mathrm{R}=\mathrm{CH}_{3}, \mathrm{Ph}, 4-\mathrm{NO}_{2} \mathrm{C}_{6} \mathrm{H}_{4}$

Scheme (2)

\section{REFERENCES}

1) K.Y.D.AL-Zubaedi, (1993), "Preparation of some heterocyclic compounds ( oxadiazole, thiadiazole triazole )", M.Sc.Thesis, University of Mosul, Mosul-Iraq.

2) M. T. Wu, (1972), J. Heterocyclic Chem., 9, 31.

3) S. W. Kim, S. C. Shim, B. J. Jung and H. K. Shim, (2002), m polymer $43,4297$.

4) A. A. Kadi , N. R. El-Brollosy , O. A. Al - Deeb , E. E. Habib , T. M. Ibrahim and A. A. El-Eman, (2007), European J. of Medicinal Chemistry, 42, 235.

5) P.Muthumani , R.Meera ,S. Bansal Agarwal,P.Devi,B. Kameswari and R. Muthuppandi , (2009), Der pharma chemica; 1(1) : 167.

6) T. Ramalingm , A. A. Deshmukh , P. B. Sattur , U. K. Sheth and S.R.Niak, (1981), J. Indian Chem. Soc., LVIII , 269.

7) A. Tantawy, A.EL - Din and M. Bbarghash , (1989) Alexandria, J. pharm. Sci. 3, 94; Chem. Abst, (1990), 112, 55719 c.

8) M.Hejsek and I.Wiedermannova,(2001), Chemica,40,15

9) T.J.Kress and S.M.Costantino,(1980),J.Heterocyclic Chem.,17,607.

10) A.Foroumadi,M.Mirzaei and A.Shaee,(2001),IL Farmaco., 56, 621. 
11) Ch. G. Bonde, A.Peepliwal and N. J. Gaikwad, (2010), Archivder pharmazie, Vol.343,Issue 4, 228.

12) G.A.Kilcigil,C.Kus,N.Altanlar,S.Ozbey, (2005),Turk. J. Chem., 29 pp. 153-162.

13)

.Zamant, K.Faghihi, T.Tofighi and M.R.Shariatzadeh, (2004) , Turk.J. Chem.,28,95 .

14) B. S. Holla and K.V. Udupa,(1992), Farmaco., 47(3), 305.

15) A. Kshirsagar, M. Toraskar, V. M. Kulkarni, S. Dhanashire and V.Kadam , (2009), International Journal of Chem tech Research, Vol. 1,No.3, 696.

16) K. M. Daoud, A. Kh.Ahmad and A.N.Ali,(2009), J. Edu. And Sci. Vol. (22), No. (3), 11 .

17) B. S. Holla, B. Veerndra, m. k. shivanade and B. poojary, (2003), European Med. Chem. , 38, 759.

18) A.I.Vogel (1965), "A text-book of practical organic chemistry ",3 rd. Edu., Longman Group Ltd., London, 254.

19) S. Parrasion and G. A. Brieux, (1963), Bull. Soc. Chem. France, 35, Chem. Abstr., (1963), 58.

20) H. Rajak, M. D. Kharya and P. Mishrd, (2007), Yakugaku, Zassshi, 127(10), 1757-1764 .

21) A. Farghaly and H. El-Kashef, (2006), Eur. J. Med.Chem. ,31, 629634.

22) U.Misra,A.Hitkari,A.Saxena,S.Gurtuand K.Shanker,(1996), Eur. J. Med.Chem. ,31, 629-634.

23) A.Amir and Shikha, (2004), J.Europ.Med.Chem.,39,353.

24) D.Hang He, Y.Chuang Zhu, Z.RuYang, A.Xihu and G.Cao,(2009), Turk J. Chem., 33, 393.

25) V.Padmavathi,G.S.Reddy,A.V.N.Mohan andK. Mohesh , (2008), Arkivoc , (Xvii), 48.

26) A. H. K. Sharba, R. H. Al-Bayati, N. Rezki and M. Awad, (2004), Heterocycles in organic and Comb-inatorial Chemistry, 12-17.

27) M.M.Dutta,B.N.Joswami and J.C.S.Kataky, (1986),J. Heterocyclic Chem., 23, 793.

28) B.N.Goswami,J.C.S.Kataky and J.N.Baruah,(1984), J. Heterocyclic Chem., 21, 1225. 